\title{
Assessment of Food Insecurity among Almajiri in Sokoto Metropolis and Selected Environs (Gwadabawa and Kware), Sokoto State, Nigeria
}

\section{* 1'SARKINGOBIR, Y; ${ }^{2}$ SAHABI, M; ${ }^{3}$ SAADU, A; ${ }^{4}$ BELLO, MM; ${ }^{1}$ BAKWAI, MS}

\author{
${ }^{*}$ Department of Biology, ${ }^{2}$ Department of Integrated Science, Shehu Shagari College of Education, Sokoto, Nigeria \\ 3. General Studies Department, College of Agriculture Wurno \\ 4. Sultan Abdurrahman College of Health Technology Gwadabawa,Sokoto, Nigeria \\ *Corresponding Author Email: Superoxidedismutase594@gmail.com \\ Tel: +2349096266980
}

\begin{abstract}
This paper aimed to assess food insecurity among Almajiri in Sokoto metropolis and it's environs using a structured questionnaire on 120 respondents. The respondents were Muslims, Hausa/ Fulani, males and Nigerians. The occupations of Almajiri fathers were, farming (66.7\%), business ( $16.7 \%)$, and $16.7 \%$ were doing nothing. $33.3 \%$ of their fathers were married to two wives, $25.0 \%$ married to three wives , $16.7 \%$ married to one wife each and , $16.7 \%$ married to four wives $.33 .3 \%$ of the Almajiri said their fathers have two children, $25.0 \%$ said their fathers have three children, and $8.3 \%$ have four kids , and $8.3 \%$ have one child .None of the participants attended western school ,but only $25.0 \%$ admitted that they like "Boko " ( western education), while 75\% said they don't like "Boko ".58.3\% goes home only after one year stay at the school, $25.0 \%$ return after graduation, $16.7 \%$ return home after 3years stay at school. $50.0 \%$ said they always come with insufficient food from home, but $41.7 \%$ said they come with nothing. $7.3 \%$ come with insufficient money from home, whereas, $41.7 \%$ come with nothing. $41.7 \%$ eat food thrice, $25.0 \%$ eat twice, and $16.7 \%$ eat once $.58 .3 \%$ earn through begging, $25.0 \%$ earn through domestic work , and $16.7 \%$ earn through external work $.75 .0 \%$ eat $t u w o$,and $16.7 \%$ eat Gari ,and others. All the respondents echoed that the system hurt them psychologically. The findings revealed that Almajiri children were unable to come with enough food or money to sustain them throughout their stay at school. Thus, this depicts food insecurity, which in turn can invariably lead to hunger.Parents should give sufficient provisions to their wards whenever sending them to Almajiri schools. The government, wealthy persons and relations should fully put hands on deck to help Almajiri child.
\end{abstract}

\section{DOI: $\underline{\text { https://dx.doi.org/10.4314/jasem.v23i9.3 }}$}

Copyright: Copyright (C) 2019 Sarkingobir et al. This is an open access article distributed under the Creative Commons Attribution License (CCL), which permits unrestricted use, distribution, and reproduction in any medium, provided the original work is properly cited.

Dates: Received: 12 June 2019; Revised: 13 July 2019; 28 July 2019

Keywords: Food insecurity, Almajiri, child labour, domestic work

Knowledge is a special gift and wealth that distinguished humans from other creatures. It is a wisdom and the highest pinnacle that can be attained in life and is obtained through school and grapple. That is why in Islam, it is exhorted that Muslims must seek knowledge of various fields of human endeavours. In fact, the first message descended to Prophet Muhammad (peace be upon him) was a stimulation to stand up and seek for knowledge. All the past prophets (peace be upon them) flourished because of knowledge (Ali,1987; Abd, 1996). The word Almajiri was drawn from Arabic word Almuhajir the migrator .It entails a person who abandoned his home and went to another town or village in the cause of religion. Whereas, Almajiri (the Hausa word) refers to a pupil or student who left his hometown to another town in search for knowledge (at Makarantar Allo or Zaure). The plural are Almajirai and are taught by Malam or Alaramma etc. The practice has a long tradition and history in Hausa land ,probably since the advent of Islam in the region .In the olden days, the Almajiri practice worked smoothly without hitch ,because there was surplus funding from government ( by the Emirs ), wealthy people and the public. When the colonial forces took over the mantle of affairs, the usual Almajiri funding halted ,because the Western education has more attention. The wealthy individuals too halted the payment of Zakat and the public neglected the Almajiri practice. Since then, the practice is languishing helplessly (Amzat, 2016). Sokoto caliphate ( as ceremoniously and traditionally called) serve as the centre and pivot of Islam in the olden and present days in Nigeria .It is a mother of the North, thus it is a typical place where the Almajiri is currently been practiced. Like in other places, the Almajiri system of nowadays is decisively marred by many problems. You can see the children and young ones wander for food ,begging ,labouring, some live or sleep on the streets, their garments are looking very untidy and unkempt.They can be source of labour or recruits for various crimes and vices in the society. These are some of the unfurtunateness Almajiri is sinking in nowadays, albeit there are some good sides in the system and some few of them are not affected by these bad situations (Aghedo and Eke,2013; Nigeria Research Network, 2013).

Islam see childhood with hope and inspiration, as something to safeguard .It is a gift that should be protected, reared and guarded. That is why, the 
children and young ones have emphatic rights .The right to have a healthy start, the right to healthcare, the right to proper nutrition, the right to dignity of life, the right to receive from society, government, and the right to education and skill acquisition among others ( Alazhar University/ UNICEF, 2005; Saiful, 2015). Holy Quran says "Should he keep her with dishonour or bury her in earth?". This is a strong criticism and caveat to those that maltreat female scions, and male alike (Saiful, 2015). One public health concern about nowadays Almajiri is the issue of food insecurity and hunger .Food is vital for existence and normal functioning of all biological systems, let alone the bigger animals, the Homo sapiens (Food and Agriculture Organization of the United Nations, 2018) .Even in the Holy Quran ,health has been emphasized and food is one of the ingredients required to maintain it ( Alazhar University/ UNICEF, 2005).

Children or teen who strive with hunger are sick more often, recover more slowly and are more likely to be hospitalized. They lack enough biological fuel to concentrate and perform less in school. They have higher levels of behavioural, emotional, aggressive and anxious problems. Their academic is usually low (American Academy of Paediatrics, 2015). Hunger and food insecurity can excavate Almajiri to indulge in various acts that are harmful to their health and the public (Food Research and Action Centre, 2017). One of the things that is also harmful to health, which hunger and food insecurity plunged Almajiri into is the child labour ( begging, domestic work and street work ) ( Onoyase ,2010; Amuda , 2015; Nwazuoke and Igwe , 2018 , ). Begging can expose them to several hazards such as accident, rape, kidnapping, trafficking, violence, drug use etc. Domestic child labour remain source of exposure to long working hours and hardly quantifiable. The practice is prone to, rape, drug, and relations (Fassa et al, 1999; Agbo, 2017). Consequently, this paper determined the level of food insecurity among Almajiri, hunger potential, causes, compensation (adaptive) mechanism (begging and domestic work, parables of child labour) and suggestions for curtailing the issues.

\section{MATERIALS AND METHODS}

Study area: The study was conducted in Sokoto Metropolis, Gwadabawa and Kware local governments, Sokoto State, Nigeria.

Study design: The type of study design used in this work was descriptive survey. Therein, an interview of participants was carried out .The 120 Almajiri were drawn using simple random sampling strategy.

Data instrument and management: The collected data was obtained in semistructured questionnaire.Then, treated using thematic network analysis and descriptive parameters of frequency and percentage were yielded.
Data analysis: The collected data was analyzed using thematic content analysis, particularly with thematic networks in Microsoft excel to yield descriptive parameters of frequency, and percentage.

\section{RESULTS AND DISCUSSIONS}

The result for this study was presented in table 1.The respondents were Muslims, Hausa/ Fulani, males and Nigerians. The major occupations of Almajiri fathers were, farming $(66.7 \%)$, business $(16.7 \%)$, and $16.7 \%$ were doing nothing. $33.3 \%$ of their fathers were married to two wives, $25.0 \%$ married to three wives, $16.7 \%$ married to one wife each and; $16.7 \%$ married to four wives $.33 .3 \%$ of the Almajiri said their fathers have two children, $25.0 \%$ said their fathers have three children, and $8.3 \%$ have four kids, and $8.3 \%$ have one child. Pertaining western education, none of the participants attended western school, but only $25.0 \%$ admitted that they like Boko ( western education), while $75 \%$ said they don't like Boko $.58 .3 \%$ return home only after one year stay at the school ,25.0\% return after graduation, whereas, $16.7 \%$ return home after 3 yrs stay at school. $50.0 \%$ said they always come with insufficient food from home ,but $41.7 \%$ said they come with nothing. $7.3 \%$ come with insufficient money from home, whereas , $41.7 \%$ come with nothing. $41.7 \%$ eat food thrice, $25.0 \%$ eat twice, and $16.7 \%$ eat once $.58 .3 \%$ earn through begging, $25.0 \%$ earn through domestic work ,and $16.7 \%$ earn through external work $.75 .0 \%$ eat tuwo ,and $16.7 \%$ eat Gari ,and others. All the respondents echoed that the system hurt them psychologically. American Psychological Association (n.d.) said the children with food problems experience psychological effects .From these findings, it can be seen that, Almajiri children failed to come with enough food or money to sustain them throughout their stay at school .Moreover, this determined that, the main food of the Almajiri children is the carbohydrate, which they got in an uncertain, unacceptable and socially problematic way. Remnants, lowly, and unchosen food is served to the pupils. Thus, this depicts food insecurity, which inturn can invariably lead to hunger. They have to embroiled in child labour to succour some of the situations. Children are precious, and gifts that need care " Each of you is a shepherd and each of you is accountable for his or her flock" ....and Allah has made for you wives of your kind and has made for you from your wives, sons and grandsons and has bestowed on you good provision. Qur'an:Nahl, 74 ( Ali, 1987). "Wealth and children are the adornments of the life of this world" Qur'an: the Cave, 46 (Ali, 1987). The Islamic Shari'ah assures the child's right. He has the right to be born, the right to be protected from any harmful exposure. A child has the right to have intellectual training and education, he has the right to health. "And do not throw yourselves into destruction "Qur'an:The Haifer, 195.Islam instruct that children and adults should be protected from violence, sexual abuse ,social abuse, psychological abuse 
,infliction of hardship or harm are all forbidden in Islam . In the same vein, the right of children to education should be reserved. (Saiful, 2015) .Holy qur,an says he keep her with dishonour ,or bury her in earth ? (Ali, 1987). This is a strong criticism and warning at those that maltreat female scions, and male alike. All the aforementioned are from the Islamic perspective.

Table 1: Assessment of food insecurity determinants among Almajiri in Sokoto Metropolis and its selected environs ( Gwadabawa and

\begin{tabular}{|c|c|c|}
\hline & Frequency & Percentage \\
\hline \multicolumn{3}{|l|}{ Demography } \\
\hline \multicolumn{3}{|l|}{ Age } \\
\hline $1-6$ & 10 & 8.3 \\
\hline $6-9$ & 10 & 8.3 \\
\hline $10-12$ & 10 & 8.3 \\
\hline $13-16$ & 40 & 33.3 \\
\hline \multicolumn{3}{|l|}{ Sex } \\
\hline Male & 120 & 100.0 \\
\hline \multicolumn{3}{|l|}{ Religion } \\
\hline Islam & 120 & 100.0 \\
\hline \multicolumn{3}{|l|}{ Tribe } \\
\hline Hausa/ Fulani & 120 & 100.0 \\
\hline \multicolumn{3}{|l|}{ Occupation of father } \\
\hline Farming & 80 & \\
\hline Business & 20 & 16.7 \\
\hline Nothing & 20 & 16.7 \\
\hline \multicolumn{3}{|l|}{ No of wives of father } \\
\hline One & 10 & 8.3 \\
\hline Two & 40 & 33.3 \\
\hline Three & 30 & 25.0 \\
\hline Four & 10 & 8.3 \\
\hline \multicolumn{3}{|l|}{ Number of children of father } \\
\hline Three & 10 & 8.3 \\
\hline Five & 30 & 25.0 \\
\hline Six & 50 & 41.7 \\
\hline \multicolumn{3}{|l|}{ Literacy of children } \\
\hline \multicolumn{3}{|l|}{ Do you like western education? } \\
\hline Yes & 60 & 50.0 \\
\hline No & 50 & 41.7 \\
\hline \multicolumn{3}{|l|}{ Do you come with food from home? } \\
\hline Yes & 10 & 50.0 \\
\hline No & 50 & 41.7 \\
\hline \multicolumn{3}{|l|}{ Do you come with money from home? } \\
\hline Yes & 10 & 8.3 \\
\hline No & 50 & 41.7 \\
\hline \multicolumn{3}{|l|}{ How many times do you eat daily? } \\
\hline Once & 20 & 16.7 \\
\hline Twice & 30 & 25.0 \\
\hline Thrice & 50 & 41.7 \\
\hline I'm psychologically hurt by my situation & 120 & 100.0 \\
\hline \multicolumn{3}{|l|}{ Source of food while at school } \\
\hline Begging & 70 & 58.3 \\
\hline Domestic work & 30 & 25.0 \\
\hline External labour & 20 & 16.7 \\
\hline \multicolumn{3}{|l|}{ Type of food mostly eaten by Almajiri } \\
\hline Tuwo / gari & 90 & 75.0 \\
\hline Gari & 20 & 16.7 \\
\hline Other & 10 & 8.7 \\
\hline \multicolumn{3}{|l|}{ Which time do you return home? } \\
\hline Yearly & 70 & 58.3 \\
\hline After three years & 20 & 16.7 \\
\hline After graduation & 30 & 25.0 \\
\hline \multicolumn{3}{|l|}{ Do you like boko } \\
\hline Yes & 30 & 25.0 \\
\hline No & 90 & 75.0 \\
\hline
\end{tabular}

Based on this work, these Almajiri were exposed to food insecurity, hunger, begging, child labour and psychological hurt .This is contrary to Islamic and Public Health provisions .Food insecurity refers to limited or uncertain availability of adequate safe food nutrients. It also includes the limited or uncertain ability to get food in a socially acceptable ways (Okolo and Obidigbo, 2015).Food insecurity have direct and indirect impacts on children in short and long terms .These impacts includes on physical, psychological, and mental health .It excavates malnutrition, lower food insecurity is associated with higher probability of hypertension, coronic heart disease, hepatitis, stroke, cancer, asthma, diabetes, arthritis, and kidney disease. Thus, food insecurity is a strong predictor of higher hospital use and increased health costs (FRAC, 2017). 
Globally, 1 out of 3 persons are in food problem. In response to that so many steps were took, one of which is the Sustainable Development Goals .Therein, a call is displayed seeking to end hunger (SDG2) (Okolo and Obidigbo, 2015; Olomola, 2017; Abubakar, 2018). Food insecurity is closely linked to hunger and malnutrition and is of serious public health concern in Nigeria .Here, there are about 17 million people that are experiencing food insecurity. This prevalence is projected to increase to 43 million in 2022 if the trend persists (FAO, 2018). Like the adults, the children have many problems because of food insecurity. Some of the public health concerns about the Almajiri child are

Psychological effects:

- $\quad$ Food insecurity and hunger can cause toxic stress ( Chilton and Jenny ,2012)

- It affect cognitive capacity

- Food insecure individuals are stigmatized

- $\quad$ Food insecurity is associated with high risk of sickness, such as stomachache, headache, cold etc. Severe form is associated with anxiety, low academic achievement

- It also lead to shame on children (APA, n.d.)

b. Behavioural effects

- Make children less attentive, independent and curious

- $\quad$ Make children to lose self-confidence , and self esteem

- Make children prone to irritability and nervousness (K- State Research and Extension, 2013). Workers who were exposed to hunger as children are not prepared like their counterparts. Workers who were exposed to hunger as children are less competitive, and seriously restrict human capital (Cook and Jeng, 2009). Children who experienced severe hunger are five times more likely to need counselling. They have more risks of chronic diseases, and more consumers of healthcare resources (Gundersen et al., 2011).

The respondents in this study opined the coping strategies they applied due to hunger and food insecurity. The strategies are begging, external and domestic work. Both of the trio are types of child labour .Firstly, begging is a widely practice norm in the Sahelian states, thus it is not new to quote begging as an alternative or coping strategy for food insecurity and hunger (UNICEF, 2012). In Islam begging is abhorred unless if there is a critical excuse, that is there is no any other means .Islam stressed that guardians should provide their wards with sufficient provision for their study .But because of illiteracy, lack of awareness, poverty and lack of government intervention the begging practice among Almajiri is still trending (Dalhat, 2011; Ogunkan, 2011; Senterfeit et al.,2013; Maigari, 2017).The begging and labour can pose the Almajiri child to much hazards. They are more likely to fall into the hands of miscreants. They are cheap to engage in drugs, and other unsound vices
.They can be cut in accident, and sex exploitation (Amzat, 2008; NRN, 2013).The food insecurity, hunger and labour among Almajiri was begotten by culture, poverty, and lack of awareness (Ojo and Adebayo,2012; Ene et al., 2018). To decisively deal with the problem, government, Nongovernmental Organizations, should use Islamic teachers and other means to subvert the lack of awareness among parents, so that they become aware of the consequences of sending children to schools without provision, both in Islamic and other perspectives. They should know that ,the norm is unislamic . The community should be enlighten using some sheikhs, because the easiest way of doing that is through Muslim clerics and leaders ( the Almajiri accept words from the duo ).Additionally, poverty ,should be addressed, more opportunities for western education should be given to children (Ogunkan, 2011; Otaha, 2013; NRN, 2013; Maigari , 2017).

Conclusion: Based on the findings of this work, food insecurity and hunger remain one of the public health concerns experienced by Almajiri in Sokoto metropolis and its environs (Gwadabawa and Kware) of Sokoto State.

\section{REFERENCES}

Abd, AR (1996). The upbringing of children in Islam .The truth Montreal Canada: Canada .www.as.sidq.org.

Abubakar, MS (2013). An empirical analysis of households' food insecurity in Gombe state, Nigeria. MSc thesis submitted to Department of Economics, ABU Zaria.

Ali, Y.A. (1987). The holy Qur'an: English Translation of the meanings. KSA: King Fahad Holy Quran Printing Complex.

Agbo, CM (2017). The health and educational consequences of child labour in Nigeria. Health. Sci. J. 11(1): 1-9.

Aghedo, I; Eke, J.S. (2013). From alms to arms: the Almajiri phenomenon and internal security in northern Nigeria .Korean J. Policy Stud.. 28 (3):97-123.

American Academy of Paediatrics (2015). Promoting food security for all children. Paediatrics, 38 (2): $135-150$.

American Psychological Association (n.d.). What are the psychological effects of hunger on children? .www.APA.org/about/gv/pi.

Amuda, JY (2015). Working conditions and consequences of child labour in Nigeria. OIDA Inter. J. Sustainable Develop. 1(7): 53-72. 
Amzat, J (2008). Lumpen childhood in Nigeria: a case of the Almajiri in Northern Nigeria.

Chilton, M; Jenny, R (2012). Toxic stress and children hunger over the life course: three case studies .J. Appl. Res. Children: Inform. Policy. Children. Risk 3 (1) :1-29.

Cook, J; Jeng K (2009). Child food insecurity: the economic impact on our nation .A report on research on the impact of food insecurity and hunger on child health, growth, and development commissioned by Feeding America and the ConAgra Foods Foundation.

Dalhat, Y (2016). Social welfare and the problem of begging in Nigeria. J. Human. Soc. Sci. 21(12):711 .

Ene, OI; Onyishi, AO; Uche, OA; Uche, IB (2014). Food insecurity in Niger: a thematic exposition .Arabian J. Bus. Manage. Rev. 4(1): 1-14.

Fassa, GA; Facchini, AL; Dall'Agnol, Christian, D (1999). Child labour and health: problems and perspectives. Inter. J. Occupational. Environ. Health. 160:1-17

Food and Agriculture Organization of the United Nations, FAO, (2018): Achieving zero hunger in Africa by 2025 .www.fao.org/publications.

Food Research and Action Centre, FRAC, (2011). Hunger is a US health issue .www.alliancetoendhubger.org.

Gundersen, CE; Waxman, E; Engelhard, D; Brown, J (2011). Map the meal gap: child food insecurity .Feeding America.

K-State Research and Extension, KSRE, (2013). 4-H : Empoweing youth to end hunger in their communities toolkit .www.ksre.KSU.edu.

Maigari, TY (2017). The Almajiri palaver in Northern Nigeria: how Islamic? Saudi J. Human. Soc. Sci. 2(5): 396-404.

Nigeria Research Network (2013). Almajiri in Birth Nigeria: a collective responsibility.
Nwazuoke, NA; Igwe, AC (2016). Worst forms of child labour in Nigeria: an appraisal of international and local legal regimes .Beijing Law Review, 7: 69-82.

Okolo, VC; Obidigbo, C (2015). Food security in Nigeria: an examination of food availability and accessibility in Nigeria. Inter. Econ. Manage. Engineer. 9(9):3171-3179.

Ogunkan, DV (2011). Begging and almsgiving in Nigeria: the Islamic perspective. Inter. J. Socio. Anthrop. 34(4):121-131.

Ojo, OE; Adebayo, FP (2012). Food insecurity in Nigeria: an overview. European J. Sustainable Develop. 1(2): 199-222.

Olomola, SA (2017). Ending rural hunger in Nigeria: effective resource management for improved food and nutrition security in Nigeria.

Onoyase, A. (2010). Effective methods of combating begging in Nigeria as perceived by panhandled. Stud. Home Comm. Sci. 4(2):109-114.

Otaha, IJ (2013). Food insecurity in Nigeria: way forward. African Research Review, 7(4):2635USAID (2018). Nigeria: nutrition profile.

Saiful IM. (2015). Fundamental human rights towards childhood: Islamic guidelines are unique to protect the child .J. Pacific Studies, 4(2): 177202.

Senterfeit, JW; Long, A; Shih, M; Teutsch, SM (2013). How social and economic factors affect health .Social Determinants of Health, issue no 1 Los Angeles: Los Angeles County Department of Public Health .Retrieved from www,publichealth.lacounty.gov/epi.

UNICEF / Al-azhar University (2005). Children in Islam: their care, upbringing and protection. USA: Cynthia Space Printing Services, New York.

UNICEF (2012). Children begging for Quranic school masters' .UNICEF briefing paper on children working in West and Central Africa. 